Dinamika Interspatial Total Factor Produktivity Usaha Perikanan Budidaya Air Tawar dan Implikasinya

Terhadap Perekonomian Wilayah Jawa Barat

(Asep Agus Handaka Suryana, Akhmad Fauzi, Bambang Juanda, dan Ernan Rustiadi)

\title{
DINAMIKA INTERSPATIAL TOTAL FACTOR PRODUKTIVITY USAHA PERIKANAN BUDIDAYA AIR TAWAR DAN IMPLIKASINYA TERHADAP PEREKONOMIAN WILAYAH JAWA BARAT
}

Asep Agus Handaka Suryana ${ }^{1}$, Akhmad Fauzi², Bambang Juanda ${ }^{3}$, dan Ernan Rustiadi ${ }^{4}$

${ }^{1}$ Dosen Fakultas Perikanan dan Ilmu Kelautan Universitas Padjadjaran Bandung.

${ }^{2}$ Guru Besar pada Departemen Ekonomi Sumberdaya dan Lingkungan, FEM, IPB

${ }^{3}$ Guru Besar pada Departemen Ilmu Ekonomi, FEM, IPB

${ }^{4}$ Dosen pada Departemen Evaluasi Sumberdaya Lahan, Faperta, IPB

E-mail: asepagus@unpad.ac.id

\begin{abstract}
ABSTRAK. Penelitian bertujuan menganalisis produktivitas dalam perikanan budidaya air tawar di Jawa Barat telah dilakukan pada bulan Juni 2012 sampai Januari 2013. Data yang digunakan berupa data primer diambil dari 273 responden pembudidaya di Kabupaten Bandung, Cianjur, Subang dan Indramayu secara purposive. Dalam penelitian ini, digunakan Interspatial Total Factor Productivity (TFP) yang merupakan variant dari Tornquist Index untuk menjelaskan perbedaan produktivitas interspasial sistem budidaya perikanan air tawar di Jawa Barat. Indeks TFP kemudian diregresikan terhadap luas lahan budidaya, kualitas benih, kualitas pakan dan dummy sistem budidaya untuk mengestimasi faktor-faktor yang mempengaruhi tingkat TFP. Berdasarkan data sekunder nilai tengah index interspatial TFP dalam sistem budidaya kolam 0.636 sampai 2.965, dalam sistem budidaya mina sawah 0.310 sampai 3.050, dan dalam KJA mulai dari 0.908 sampai 1.737 Nilai TFP dari data primer mulai dari 0.697 sampai 2.133. Hasil regresi memperlihatkan variabel kualitas benih dan kualitas pakan memainkan peran paling dominan terhadap peningkatan nilai TFP. Perubahan TFP berimplikasi terhadap Produk Domestik Regional Bruto, Pendapatan Asli Daerah, dan Tenaga Kerja Perikanan Jawa Barat.
\end{abstract}

Kata kunci: Total Factor Productivity, budidaya perikanan air tawar, ekonomi wilayah

\section{DYNAMICS OF TOTAL FACTOR PRODUCTIVITY INDEX IN FRESHWATER AQUACULTURE AND THEIR IMPACT ON REGIONAL ECONOMY IN WEST JAVA}

\begin{abstract}
ABSTRACK.The study aims to analyze the productivity in West Java Freshwater aquaculture have been conducted in Juny 2012 until January 2013. Secondary data carried from West Java fisheries statistic. Primary data collected by purposive sampling from Bandung, Cianjur, Subang, and Indramayu distric fish farmer. In this study, we use a variant of the Tornquist Index, aTFP index, to examine the interspatial productivity differences of freshwater aquaculture in West Java practicing various forms of freshwater pond, paddy field culture and floating cage net. TFP indexes are obtained from seed, labor, feed, as variable inputs and fish production as variable output, adjusted by the input cost and output revenue for each district or farm. Estimated index Interspatial TFP value on West Java Freshwater aquaculture on pond range from 0.636 to 2.965, paddy field range from 0.310 to 3.050, floating cage net range from 0.908 to 1.737, and on individual fish farmer range from 0.697 to 2.133. Results of the regression show that quality of fish seed and feed plays a main role in achieving high TFP. Change of TFP have implication to Domestic Product Regional Bruto, and Fishery Labour of West Java.
\end{abstract}

Keyword: Total Factor Productivity, Freshwater aquaculture, regional economic

\section{PENDAHULUAN}

Jawa Barat sebagaimana daerah lain di Indonesia masih menghadapi permasalahan pembangunan berupa jumlah penduduk miskin yang cukup banyak (menurut BPS sebanyak 4,8 juta jiwa pada tahun 2011). Berbagai strategi pembangunan tentunya harus dilakukan, serta optimalisasi sumberdaya yang ada juga harus dikerahkan untuk mengentaskan kemiskinan tersebut. Salah satu sumberdaya yang dapat dioptimalkan untuk menggerakan perekonomian adalah pengembangan perikanan budidaya air tawar.

Terlihat dalam Gambar 1, Jawa Barat merupakan salah satu provinsi yang memiliki areal budidaya, jumlah pembudidaya, dan kontribusi produksi perikanan air tawar yang terbesar di Indonesia. Budidaya perikanan sendiri merupakan usaha yang telah lama dikenal di Jawa Barat, baik budidaya yang sifatnya subsisten maupun yang bersifat komersial. Namun meskipun budidaya perikanan air tawar telah lama dikenal di Jawa Barat, perkembangannya belum menggembirakan. Hal ini dapat dilihat dari

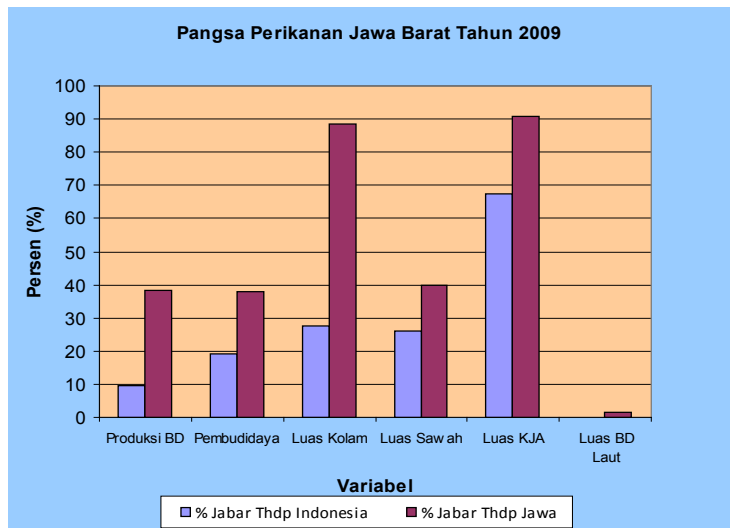

Gambar 1. Pangsa Perikanan Jawa Barat terhadap Indonesia Tahun 2009

produktivitas, tingkat kesejahteraan pembudidaya yang masih rendah.

Kontribusi perikanan air tawar Jawa Barat yang besar perlu terus dipertahankan bahkan dikembangkan. Hal ini perlu mendapatkan perhatian, karena data menunjukkan bahwa ada kecendrungan stagnasi bahkan penurunan kontribusi perikanan Jawa 
Barat akhir-akhir ini. Penurunan ini terdapat dalam prosentase produksi total, prosentase pembudidaya, dan produksi beberapa jenis ikan. Rincian mengenai trend pangsa perikanan budidaya air tawar di Jawa Barat dapat dilihat dalam Gambar 2.



Gambar 2. Trend Pangsa Perikanan Budidaya Air Tawar Jawa Barat 2005-2009

Berbagai penelitian di berbagai wilayah seperti yang dikemukakan Fauzi (2010), World Bank (2007), Bene (2006), Tacon (2001) dan Edward (1999) menyimpulkan bahwa pengembangan perikanan budidaya sangat penting terus dilakukan. Hal ini karena perikanan budidaya dapat menyediakan protein hewani terjangkau, menguatkan ketahanan pangan rumah tangga, dapat menyediakan kesempatan kerja, mendukung keberlangsungan industri primer yang banyak keterkaitannya, berkontribusi terhadap pengentasan kemiskinan dan berkontribusi terhadap pertumbuhan ekonomi wilayah.

Pengembangan perikanan budidaya pada saat ini sangat strategis jika pengembangannya ke arah peningkatan produktivitas. Hal ini karena berbagai keterbatasan yang ada terutama lahan dan air menjadikan peningkatan produktivitas yang berarti intensifikasi merupakan arah pengembangan yang harus terus di dorong. Oleh karena itu perlu analisis mengenai tingkat produktivitas usaha budidaya perikanan air tawar saat ini serta faktor-faktor yang berpengaruh signifikan terhadap produktivitas perikanan budidaya air tawar ini.

Berbagai program untuk meningkatkan produksi perikanan terus dilakukan seperti Inbudkan (Intensifikasi Budidaya Perikanan), Protekan (Program Peningkatan Produksi Perikanan) sampai program Minapolitan yang baru-baru ini dicanangkan. Berbagai program tadi belum memperlihatkan hasil yang signifikan bila dilihat dari peningkatan produktivitas maupun kesejahteraan pembudidaya. Oleh karena itu perlu kajian yang mendalam berkaitan dengan produktivitas dan faktor-faktor yang mempengaruhinya. Ukuran produktivitas yang digunakan dalam penelitian ini adalah Total Factor Productivity. Penelitian ini bertujuan (1) menganalisis tingkat produktivitas perikanan budidaya air tawar baik perkembangan tingkat produktivitas maupun tingkat produktivitas perikanan budidaya air tawar eksisting di Jawa Barat saat ini. (2) menganalisis faktor-faktor yang mempengaruhi tingkat produktivitas perikanan budidaya air tawar di Jawa Barat (3) Menganalisis implikasi dinamika produktivitas perikanan budidaya air tawar terhadap perekonomian wilayah Jawa Barat.

\section{Lokasi dan Waktu Penelitian}

Pengambilan data primer dilakukan di Kecamatan Bojongsoang Kabupaten Bandung, Kecamatan Mande Kabupaten Cianjur, Kecamatan Pabuaran Kabupaten Subang dan di Kecamatan Pasekan Kabupaten Indramayu Provinsi Jawa Barat. Pengumpulan data dilakukan pada bulan Oktober sampai Desember 2012.

\section{Jenis dan Sumber Data}

Jenis data yang digunakan dalam penelitian ini terdiri dari data primer dan data sekunder. Data primer diperoleh dari hasil penyebaran kuesioner kepada para pembudidaya di lokasi pengambilan sampel. Data primer berupa seluruh komponen biaya input serta output yang dihasilkan dalam budidaya. Jumlah responden sebanyak 276 orang pembudidaya di KJA, kolam dan sawah yang tersebar di empat kabupaten. Data sekunder berupa data runtun waktu jumlah produksi, input pakan, tenaga kerja dan benih. Data sekunder dikumpulkan sejak tahun 1997 sampai tahun 2011.

\section{Metode Analisis Data}

\section{Indeks Interspatial Total Factor Produktivity (TFPI)}

Untuk menghitung indeks Interspatial TFP digunakan rumus yang digunakan Cordero dkk. (1999) yang mengikuti persamaan berikut:



$$
\begin{aligned}
& \mathrm{TI}_{\text {iavg }}=\text { Indeks TFP } \\
& \mathrm{Q}_{\mathrm{mi}}=\text { Jumlah output dalam budidaya spesies } \mathrm{m} \\
& \text { dari pembudidaya ke-i (Rp) } \\
& \mathrm{Q}_{\mathrm{avg}}=\text { Jumlah output rata-rata dalam budidaya } \\
& \text { spesies } m \text { dari } n \text { pembudidaya }(\mathrm{Rp}) \\
& \mathrm{s}_{\mathrm{mi}} \quad=\text { Pendapatan pembudidaya ke-i dari } \\
& \text { budidaya spesies } \mathrm{m}(\mathrm{Rp}) \\
& \mathrm{s}_{\text {mavg }}=\text { Rata-rata pendapatan seluruh pembudidaya } \\
& \text { dari budidaya spesies } \mathrm{m}(\mathrm{Rp}) \\
& \mathrm{s}_{\mathrm{ki}} \quad=\text { Biaya input budidaya spesies } \mathrm{m} \text { dari } \\
& \text { pembudidaya ke-i (Rp) } \\
& \mathrm{s}_{\text {kavg }} \quad=\text { Rata-rata biaya input budidaya spesie } \mathrm{m} \\
& \text { seluruh pembudidaya (Rp) } \\
& \mathrm{X}_{\mathrm{ki}} \quad=\text { Jumlah input dalam budidaya spesies } \mathrm{m} \\
& \text { dari pembudidaya ke-i (Rp) } \\
& \mathrm{X}_{\mathrm{kavg}}=\text { Jumlah input rata-ratadalam budidaya } \\
& \text { spesies } m \text { dari n pembudidaya ( } \mathrm{Rp} \text { ) } \\
& \text { Tahun yang dijadikan tahun analisis adalah } \\
& \text { tahun 1997, 2002, } 2007 \text { dan tahun } 2011 .
\end{aligned}
$$

Analisis Faktor-Faktor yang Mempengaruhi Produktivitas

Persamaan ekonometrik yang menggambarkan pengaruh berbagai faktor terhadap TFP dalam bentuk persamaan ekonometrika ditulis sebagaimana persamaan di bawah ini.

$\ln T F P_{i}=\ln \alpha+\beta_{1} \ln L L B_{i}+\beta_{2} \ln K P K_{i}+\beta_{3} \ln K B N_{i}+\beta_{4} \ln D_{K L M_{i}}+\beta_{5} \ln D_{K J A_{i}}+\varepsilon_{i}$ 
Dimana:

$$
\begin{array}{ll}
\mathrm{TFP}= & \text { Indeks TFP } \\
\mathrm{LLB}= & \text { Luas lahan budidaya yang digunakan }(\mathrm{m} 2 \\
& \text { atau ha }) \\
\mathrm{KPK}= & \text { Kualitas pakan } \\
\mathrm{KBNH}= & \text { Kualitas benih } \\
\mathrm{D}_{\mathrm{KLM}}= & \text { Dummy variabel untuk sistem budidaya } \\
& \text { kolam }(1=\text { kolam, } 0=\text { lainnya }) \\
\mathrm{D}_{\mathrm{KJA}}= & \text { Dummy variabel untuk sistem budidaya } \\
\mathrm{KJA} \quad(1= & \text { KJA, } 0=\text { lainnya }) \\
\varepsilon_{\mathrm{i}} & \text { sisaan } \\
\mathrm{i} & \text { Pembudidaya atau kabupaten/kota ke-i (i } \\
= & 1,2,3, \ldots, \mathrm{n})
\end{array}
$$

\section{Uji Mann-Whitney}

Uji ini digunakan untuk membandingkan dua median populasi. Uji Mann-Whitney didasarkan pada jumlah rangking 2 sampel populasi. Misalnya diuji 2 sampel, yaitu $\mathrm{x}_{1} \mathrm{dn} \mathrm{x}_{2}$. Hipotesis ujinya adalah:

$\mathrm{H}_{0}$ : Distribusi sampel $\mathrm{x}_{1}$ dan $\mathrm{x}_{2}$ adalah sama.

$\mathrm{H}_{1}$ : Distribusi sampel $\mathrm{x}_{1}$ dan $\mathrm{x}_{2}$ tidak sama. Langkah-langkah melakukan uji MannWhitney adalah:

a. Membuat rangking untuk sampel pertama dan sampel kedua dari 1 sampai $\left(n_{1}+n_{2}\right)$. Dalam hal ini, $\mathrm{n}_{1}$ adalah banyaknya data dalam sampel pertama $\left(\mathrm{x}_{1}\right)$ dan $\mathrm{n}_{2}$ adalah banyaknya data dalam sampel kedua $\left(\mathrm{x}_{2}\right)$.

b. Menjumlahkan rangking untuk sampel pada sampel $\mathrm{x}_{1}$

Menghitung nilai taksiran, yaitu median selisih antara sampel pertama $\left(\mathrm{x}_{1}\right)$ dan sampel kedua $\left(\mathrm{x}_{2}\right)$.

\section{HASIL DAN PEMBAHASAN}

\section{Analisis Indeks Interspatial Total Factor Productivity Perikanan Budidaya dalam Kolam di Jawa Barat}

Perhitungan Index Interspatial TFP dilakukan dalam empat waktu, yaitu tahun 1997, 2002, 2007 dan tahun 2011. Hasil perhitungan Index Interstaial TFP sistem budidaya perikanan air tawar di kolam dapat dilihat dalam Lampiran. Berdasarkan hasil perhitungan Indeks Interspatial TFP perikanan budidaya di kolam terlihat bahwa secara umum ratarata Jawa Barat mengalami peningkatan kemudian mengalami penurunan. Bila pada tahun 1997 nilai indeks Interspatial TFP sebesar 0.830 maka lima tahun berikutnya tahun 2002 meningkat menjadi 2.632. Pada lima tahun berikutnya (2007) mengalami penurunan menjadi 1.428 kemudian tahun 2011 menjadi 0.928 . Secara umum dapat disimpulkan bahwa di Jawa Barat, dalam sepuluh tahun terakhir nilai indeks Interspatial TFP perikanan budidaya perikanan air tawar di kolam mengalami penurunan.

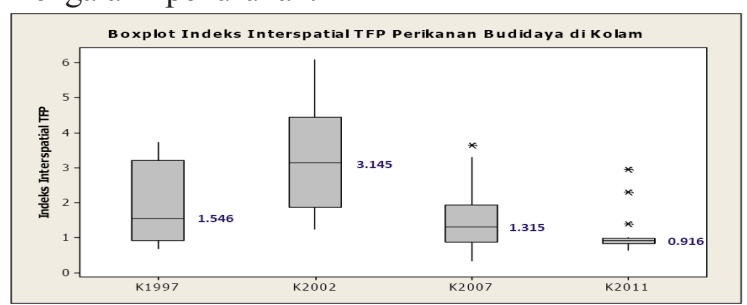

Gambar 3. Boxplot trend indeks Interspatial TFP budidaya perikanan di kolam
Trend indeks Interspatial TFP perikanan budidaya dalam kolam di Jawa Barat dalam bentuk boxplot dapat dilihat dalam gambar 3 .

Untuk mengetahui apakah diantara populasi data indeks Interspatial TFP perikanan budidaya di kolam terdapat perbedaan yang signifikan atau tidak dilakukan pengujian perbedaan nilai tengah diantara dua populasi data, dengan Uji Mann-Whitney. Hasil Uji MannWhitney untuk data-data perubahan indeks TFP perikanan budidaya di kolam terdapat dalam tabel 1 .

Tabel 1. Hasil uji Mann-Whitney nilai tengah indeks Interspatial TFP kolam

\begin{tabular}{lllllll}
\hline \multicolumn{6}{c}{ Periode } \\
\hline \multirow{2}{*}{ P-value } & $1997-2002$ & $1997-2007$ & $2007-2011$ & $2002-2007$ & $2002-2011$ & $2007-2011$ \\
& $0.0033^{*}$ & 0.3898 & $0.004^{*}$ & $0.0000^{*}$ & $0.0000^{*}$ & $0.0130^{*}$ \\
\hline
\end{tabular}

Keterangan: *) signifikan dalam taraf nyata $1 \%$

Hasil Uji Mann-Whitney menunjukkan bahwa median nilai indeks Interspatial TFP perikanan budidaya dalam kolam di Jawa Barat tahun 1997 dibandingkan dengan tahun 2002, tahun 2007 dibandingkan dengan tahun 2011, tahun 2002 dibandingkan dengan 2007, tahun 2002 dibandingkan dengan 2011, dan tahun 2007 dibandingkan dengan 2011 memiliki perbedaan yang nyata. Sedangkan median nilai indeks Interspatial TFP tahun 1997 dibanding dengan tahun 2007 tidak memiliki perbedaan yang signifikan. Hal ini menunjukkan bahwa dalam lima tahun (1997-2002) nilai indeks Interspatial TFP perikanan budidaya dalam kolam mengalami peningkatan, kemudian mengalami penurunan dalam sepuluh tahun terakhir (2002-2011).

\section{Analisis Indeks Interspatial Total Factor Productivity} Perikanan Budidaya dalam Sawah di Jawa Barat

Hasil perhitungan Indeks Interspatial TFP perikanan budidaya di sawah terlihat bahwa secara umum rata-rata Jawa Barat sebagaimana pada kolam mengalami peningkatan kemudian mengalami penurunan. Bila pada tahun 1997 nilai indeks Interspatial TFP sebesar 1.468 maka lima tahun berikutnya tahun 2002 meningkat menjadi 2.589 . Pada lima tahun berikutnya (2007) mengalami penurunan menjadi 2.219 kemudian tahun 2011 menjadi 1.055. Secara umum dapat disimpulkan bahwa di Jawa Barat, dalam sepuluh tahun terakhir nilai indeks Interspatial TFP perikanan budidaya perikanan air tawar di sawah mengalami penurunan.

Trend indeks Interspatial TFP perikanan budidaya dalam sawah di Jawa Barat dalam bentuk boxplot dapat dilihat dalam gambar 4 .

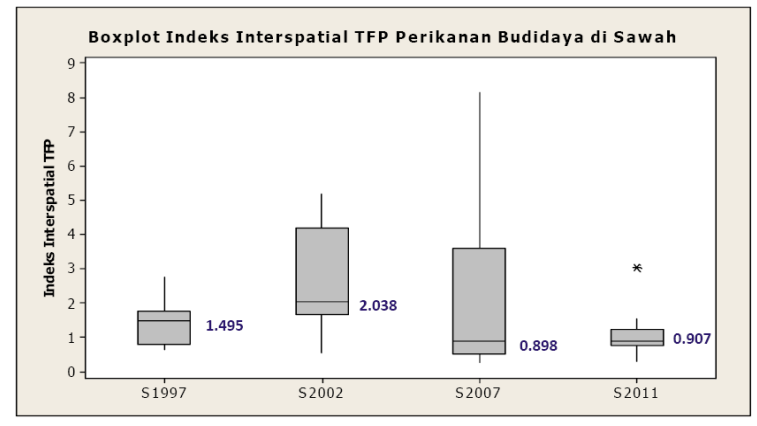

Gambar 4. Boxplot trend indeks Interspatial TFP budidaya perikanan di sawah 
Untuk mengetahui apakah diantara populasi data indeks Interspatial TFP perikanan budidaya di kolam terdapat perbedaan yang signifikan atau tidak dilakukan pengujian perbedaan nilai tengah diantara dua populasi data, dengan Uji Mann-Whitney. Hasil Uji MannWhitney untuk data-data perubahan indeks TFP perikanan budidaya di kolam terdapat dalam tabel 2.

Tabel 2. Hasil uji Mann-Whitney nilai tengah indeks Interspatial TFP sawah

\begin{tabular}{lcccccc}
\hline \multicolumn{6}{c}{ Periode } \\
\hline \multirow{2}{*}{ P-value } & $1997-2002$ & $1997-2007$ & $2007-2011$ & $2002-2007$ & $2002-2011$ & $2007-2011$ \\
& $0.0085^{*}$ & 0.4020 & 0.0549 & $0.0476^{* *}$ & $0.0000^{*}$ & 0.9892 \\
\hline
\end{tabular}

Keterangan: *) signifikan dalam taraf nyata $1 \%$

Hasil Uji Mann-Whitney menunjukkan bahwa median nilai indeks Interspatial TFP perikanan budidaya dalam sawah di Jawa Barat tahun 1997 dibandingkan dengan tahun 2002, tahun 2002 dibandingkan dengan 2007, dan tahun 2002 dibandingkan dengan 2011 memiliki perbedaan yang nyata. Sedangkan median nilai indeks Interspatial TFP tahun 1997 dibanding dengan tahun 2007, tahun 2007 dibanding dengan tahun 2011, dan tahun 2007 dibanding dengan tahun 2011 tidak memiliki perbedaan yang signifikan. Hal ini sebagaimana trend dalam budidaya dalam kolam, perikanan budidaya dalam sawah juga menunjukkan bahwa dalam lima tahun (1997-2002) nilai indeks Interspatial TFP perikanan budidaya dalam sawah mengalami peningkatan, kemudian mengalami penurunan dalam sepuluh tahun terakhir (2002-2011).

\section{Indeks Interspatial Total Factor Productivity Perikanan Budidaya dalam KJA di Jawa Barat}

Hasil perhitungan Indeks Interspatial TFP perikanan budidaya di karamba jaring apung terlihat bahwa secara umum rata-rata Jawa Barat sebagaimana pada kolam dan sawah mengalami peningkatan kemudian mengalami penurunan. Bila pada tahun 1997 nilai tengah indeks Interspatial TFP sebesar 1.495 maka lima tahun berikutnya tahun 2002 meningkat menjadi 2.038. Pada lima tahun berikutnya (2007) mengalami penurunan menjadi 1.191 kemudian tahun 2011 menjadi 0.993. Secara umum dapat disimpulkan bahwa di Jawa Barat, dalam sepuluh tahun terakhir nilai indeks Interspatial TFP perikanan budidaya perikanan air tawar di karamba jaring apung mengalami penurunan.

Trend indeks Interspatial TFP perikanan budidaya dalam KJA di Jawa Barat dalam bentuk boxplot dapat dilihat dalam gambar 4.

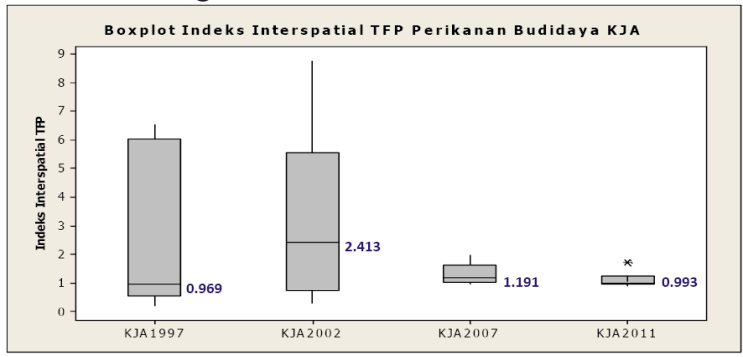

Gambar 4. Boxplot trend indeks Interspatial TFP budidaya perikanan di KJA
Untuk mengetahui apakah diantara populasi data indeks Interspatial TFP perikanan budidaya di KJA terdapat perbedaan yang signifikan atau tidak dilakukan pengujian perbedaan nilai tengah diantara dua populasi data, dengan Uji Mann-Whitney. Hasil Uji MannWhitney untuk data-data perubahan indeks TFP perikanan budidaya di KJA terdapat dalam tabel 3 .

Tabel 3. Hasil uji Mann-Whitney nilai tengah indeks Interspatial TFP KJA

\begin{tabular}{ccccccc}
\hline \multicolumn{7}{c}{ Periode } \\
\hline \multirow{2}{*}{ P-value } & $1997-2002$ & $1997-2007$ & $2007-2011$ & $2002-2007$ & $2002-2011$ & $2007-2011$ \\
& 0.6889 & 0.8102 & 0.9362 & 10.000 & 0.8102 & 0.2298 \\
\hline
\end{tabular}

Keterangan: *) signifikan dalam taraf nyata $1 \%$

Hasil Uji Mann-Whitney menunjukkan bahwa median nilai indeks Interspatial TFP perikanan budidaya dalam KJA di Jawa Barat diantara tahun 1997, 2002, 2007, dan 2001 tidak terdapat perbedaan yang signifikan. Hal ini menunjukkan bahwa dalam lima belas tahun terakhir nilai indeks Interspatial TFP perikanan budidaya dalam KJA tidak mengalami perubahan. Trendnya jika dilihat berdasarkan nilai mutlaknya mengalai penurunan dalam sepuluh tahun terakhir.

Dinamika rata-rata indeks Interspatial TFP perikanan budidaya kolam, sawah dan KJA di Jawa Barat dapat dilihat dalam gambar 5.

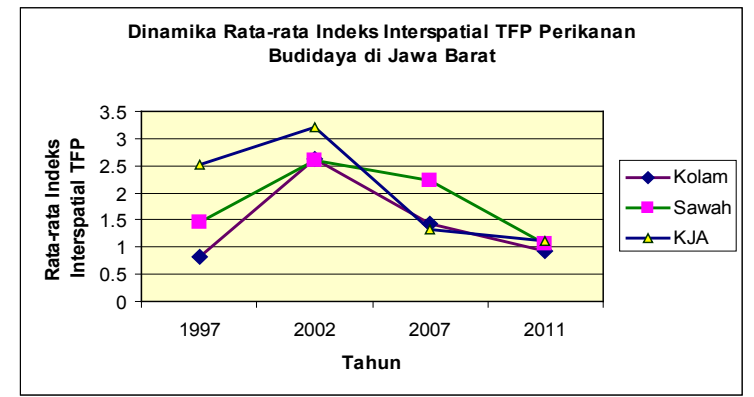

Gambar 5. Dinamika rata-rata indeks interspatial TFP perikanan budidaya di Jawa Barat

Hasil analisis yang menunjukkan bahwa selama periode 1997-2002 indeks Interspatial TFP mengalami peningkatan sedangkan selama periode 2002-2001 (sepuluh tahun terakhir) mengalami penurunan diduga disebabkan oleh beberapa faktor, diantaranya lambatnya input teknologi dalam bidang perikanan.

\section{Implikasi Dinamika TFP terhadap Perekonomian Wilayah}

Penurunan atau kenaikan produksi karena penurunan atau kenaikan produktifitas diantara perikanan budidaya air tawar yang memakai media kolam, sawah dan KJA dapat dilihat dalam gambar 6 .

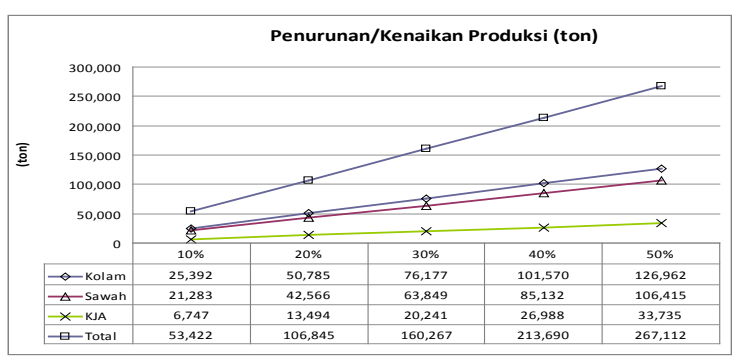

Gambar 6. Implikasi Dinamika Produktivitas terhadap Produksi 
Dari grafik terlihat bahwa perikanan budidaya yang mengalami penurunan atau kenaikan terbesar adalah perikanan budidaya yang memakai media kolam. Berikutnya perikanan budidaya yang memakai media sawah, dan terakhir perikanan budidaya yang memakai media KJA. Hal ini terutama dipengaruhi oleh faktor luas budidaya selama ini. Luasan budidaya yang terbesar adalah budidaya yang memakai media kolam, diikuti sawah dan terakhir KJA.

Dinamika nilai indeks TFP berpengaruh terhadap penurunan atau kenaikan produksi. Produksi yang dihasilkan suatu sektor itu sendiri akan berkontribusi terhadap nilai Pendapatan Domestik Regional Bruto (PDRB). Oleh karena itu dinamika nilai indeks TFP pada gilirannya akan berpengaruh terhadap penurunan atau kenaikan PDRB itu sendiri. Total nilai PDRB perikanan Jawa Barat tahun 2010 sebesar Rp. 7.412.093.270.000. Total produksi perikanan sebesar $805.199,97$ ton. Oleh karena itu dalam analisis ini digunakan fraksi penambahan PDRB sebesar Rp. 9.205.280 setiap ton produksi perikanan Jawa Barat. Bagaimana dinamika nilai indeks TFP dalam kolam, sawah dan KJA terhadap PDRB perikanan Jawa Barat dipaparkan dalam tabel 4.

Tabel 4. Simulasi Implikasi Perubahan TFP terhadap PDRB, PAD, dan Tenaga Kerja Perikanan Jawa Barat

\begin{tabular}{lcrrrr} 
& \multicolumn{5}{c}{ Perubahan TFP } \\
& $10 \%$ & \multicolumn{1}{c}{$20 \%$} & \multicolumn{1}{c}{$30 \%$} & \multicolumn{1}{c}{$40 \%$} & $50 \%$ \\
\hline PDRB (milyar Rp) & 492 & 984 & 1,475 & \multicolumn{1}{c}{2} & 2,46 \\
Pangsa (\%) & 6,63 & 13,27 & 13,9 & 26,54 & 33,17 \\
PAD (Juta Rp) & 142 & 284 & 426 & 568 & 710 \\
Pangsa (\%) & 6,63 & 13,27 & 13,9 & 26,54 & 33,17 \\
Tenaga Kerja (Orang) & 4,512 & 9,024 & 13,536 & 18,05 & 22,56 \\
Pangsa (\%) & 0,87 & 1,75 & 2,62 & 3,5 & 4,37 \\
Sumber: Hasil simulasi data & & & &
\end{tabular}

\section{SIMPULAN}

1. Perikanan budidaya ikan di sawah memiliki nilai perubahan indeks TFP dan indeks Interspatial TFP yang paling kecil, berikutnya budidaya ikan di kolam, dan terbesar di KJA.

2. Perubahan indeks TFP dan indeks Interspatial TFP di Jawa Barat menurun dalam sepuluh tahun terakhir. Hal ini diduga karena tidak adanya peningkatan input teknologi baru seperti adanya strain baru ikan yang unggul dalam sepuluh tahun terakhir.

3. Peningkatan produktivitas dapat dilakukan dengan terus menerus meningkatkan kualitas benih dan pakan. Peningkatan kualitas benih dapat dilakukan dengan mengembangkan strain-starain baru ikan budidaya. Peningkatan kualitas pakan dapat dilakukan dengan peningkatan rasio konversi pakan terhadap bobot ikan.

Berdasarkan hasil analisis produktivitas dengan pendekatan Total Factor Produktivity, maka implikasi kebijakan yang dirumuskan adalah:

a. Perlu terus menerus peningkatan kualitas benih. Peningkatan kualitas benih dapat dilakukan dengan meningkatkan tingkat kelangsungan hidup dan meningkatkan kecepatan pertumbuhan ikan. Peningkatan kualitas benih ini sangat terkait dengan pengembangan induk ikan budidaya air tawar. Pengembangan induk harus terus ditingkatkan, hal ini untuk mendorong terus lahirnya induk-induk ikan budidaya air tawar yang unggul. Hal ini terutama induk ikan-ikan yang banyak dibudidayakan seperti ikan mas, nila, lele, dan patin.

b. Perlu terus menerus peningkatan kualitas pakan ikan. Peningkatan kualitas pakan dilakukan dengan meningkatkan konversi pakan

c. Produksi ikan air tawar-terutama mas dan nila- dari KJA berkontribusi besar dalam meningkatnya jumlah produksi ikan yang dihasilkan Jawa Barat. Oleh karena itu sangat perlu memberi perhatian serius dalam mempertahankan produktivitas perikanan budidaya air tawar di KJA.

Selama ini produktivitas perikanan budidaya air tawar di KJA memiliki nilai yang tertinggi dibanding budidaya di kolam dan sawah. Namun berbagai permasalahan seperti pencemaran air dan adanya over capacity berbagai waduk tempat KJA beroperasi akan menjadi ancaman bagi tingginya produktivitas bahkan keberlangsungan perikanan budidaya di KJA.

\section{DAFTAR PUSTAKA}

Anwar, A. 2005. Ketimpangan Pembangunan Wilayah dan Perdesaan. P4Wpress. Bogor. 348 hal.

Avila, A.F.D. and R.E. Evenson. 2004. Total Factor Productivity Growth in Agriculture: the role of technological capital. Yale University, New Heaven Badan Pusat Statistik (BPS) Provinsi Jawa Barat. 2010. Jawa Barat dalam Angka. BPS. Bandung

Badan Pusat Statistik (BPS) Indonesia. 2011. Perkembangan Beberapa Indikator Utama SosialEkonomi Indonesia, Agustus 2011. BPS. Jakarta.

Cordero, M. F.J., Fitzgerald, W.J., dan Leung, P.S. 1999. Evaluation of Productivity in Extensive Aquaculture Practices Using Interspasial TFP Index, Sulawesi, Indonesia. Journal of Asian Fisheries Science. Asian Fisheries Society, Manila, Philippines. Hal 223-234.

Edward, P. 1999. Towards increased impact of rural aquaculture. Discussion paper prepared for the First Meeting of the APFIC Ad Hoc Working Group of Experts on Rural Aquaculture, FAO Regional Office for Asia and the Pacific (RAP), Bangkok, Thailand, 20-22 October, 1999.

Fauzi, A. 2010. Ekonomi Perikanan, Teori, Kebijakan, dan Pengelolaan. Gramedia. Jakarta. 224 hal.

Fauzi, A. 2010. Landasan Pembangunan Perdesaan. Dalam Buku: Pembangunan Perdesaan dalam Rangka Peningkatan Kesejahteraan Masyarakat (Ed: Chozin, M.A.dkk). IPB Press. Bogor.

Food and Agriculture Organization (FAO). 2001. Production, Accessibility, Marketing and Consumtion Patterns of Freshwater Aquaculture 
Products in Asia: A Cross-Country Comparison. FAO. Rome.

Food and Agriculture Organization (FAO). 2011. FAO Yearbook. Food and Agriculture Organization of The United Nation. Rome.

Hafsah, J. 2006. Desa itu Industri. Dalam Buku Kawasan Agropolitan: Konsep Pembangunan Desa-Kota Berimbang. (ed: Rustiadi, E., Hadi, S. dan M.A. Widhyanto). Crescent Press P4W IPB. Bogor.

Hutagaol, P. 2001. Paradigma Baru Pengembangan Perdesaan Menuju Masyarakat dan Kawasan Perdesaanyang Mandiri dalamEra OtonomiDaerah. Jurnal Studi Pembangunan, Kemasyarakatan \& Lingkungan, Vol. 3, No. 1/2001. Jakarta. Hal 1536.

Juarno, O. 2011. Daya Saing Udang Tambak Indonesia di Pasar Internasional terkait dengan Peningkatan Produktivitas dan Mutu. Disertasi IPB. Tidak dipublikasikan. Bogor.

Kementrian Kelautan dan Perikanan (KKP). 2011. Statistik Kelautan dan Perikanan . Jakarta.

Maulana, M. 2004. Peranan Luas Lahan, Intensitas Pertanaman dan Produktivitas sebagai Sumber Pertumbuhan Padi Sawah di Indonesia. Jurnal Agro Ekonomi, 22 (1):74-95.

Nemes, G. 2005. Integrated Rural Development: The Concept and Its Operation. Discussion Papers. Institute of Economics Hungarian Academy of Sciences. Budapest.

Rustiadi, E., Saefulhakim, S., dan Panuju, D.R. 2009. Perencanaan dan Pengembangan Wilayah. Crescent Press dan Yayasan Obor. Jakarta.
Sadjad, S. 2006. Desa itu Industri. Dalam Buku Kawasan Agropolitan: Konsep Pembangunan Desa-Kota Berimbang. (ed: Rustiadi, E., Hadi, S. dan M.A. Widhyanto). Crescent Press P4W IPB. Bogor.

Salim, E. 2010. Pengantar Buku Pengembangan Wilayah melalui Pendekatan Kesisteman. IPB Press. Bogor.

Suparyati, A. 1999. Analisis Dampak Keterbukaan Ekonomi dan Stabilitas Makroekonomi terhadap Pertumbuhan Total Factor Productivity Indonesia. Thesis Program Pascasarjana Fakultas Ekonomi Universitas Indonesia. Tidak dipublikasikan.

Supriyadi R, E. 2007. Telaah Kendala Penerapan Pengembangan Ekonomi Lokal: Pragmatisme dalam Praktek Pendekatan PEL. Jurnal Perencanaan Wilayah dan Kota, Vol 18 No. 2 Agustus 2007, hal 103-123.

Tacon, A.G.J. 2001. Increasing the contribution of aquaculture for food security and poverty alleviation. In R.P. Subasinghe, P. Bueno, M.J. Phillips, C. Hough, S.E. McGladdery \& J.R. Arthur, eds. Aquaculture in the Third Millennium. Technical Proceedings of the Conference on Aquaculture in the Third Millennium, Bangkok, Thailand, 20-25 February 2000. pp.63-72. NACA, Bangkok and FAO, Rome.

Tasrif, M. 2006. Analisis Kebijakan Menggunakan Model System Dynamics. Program Magister Studi Pembangunan ITB. Bandung.

World Bank. 2007. Chaning The Face of Water The Promise and Challenge of Sustainable Aquaculture. Washington. 